\title{
PENEKANAN NABATI PADA TANAH TANAMAN TOMAT TERKONTAMINASI Fusarium oxysporum F.SP. lycopersici
}

\author{
Andri Sugito, Heru Adi Djatmiko, dan Loekas Soesanto \\ Jurusan Ilmu Hama dan Penyakit Tanaman, Fakultas Pertanian, \\ Universitas Jenderal Soedirman, Purwokerto \\ lukas_262@yahoo.com
}

\begin{abstract}
[BOTANICAL SUPPRESSION ON CONTAMINATED TOMATO SOIL BY Fusarium oxysporum f.sp. lycopersici]. A screen house study was carried out to identify the best botanical materials and their application time on suppression of Fusarium oxysporum f.sp. lycopersici pathogen in contaminated soil and on the growth of tomato. A randomized block design with three replications was used allocate 19 treatment combinations of botanical materials (extract of neem leaves, clove leaves, teak bark, pine bark, and catalpha leaves) and time of applications (4, 2, or 4 and 2 weeks before planting). Observations were made on the development of the pathogen, disease intensity, and plant growth. Results showed that all botanical materials used could reduce the pathogen population but not the plant growth components. Extract of clove leaves applied at 4 weeks before planting was the best in decreasing the pathogen population $(79.22 \%)$
\end{abstract}

Keyword: soil health, clove leaves extract, tomato, Fusarium oxysporum f.sp. lycopersici

\begin{abstract}
ABSTRAK
Percobaan rumah kawat dilakukan untuk mengidentifikasi bahan-bahan nabati dan waktu aplikasi terbaik untuk menekan perkembangan Fusarium oxysporum f.sp. lycopersici dan pertumbuhan tomat. Rancangan acak kelompok dengan tiga ulangan digunakan untuk mengalokasikan 19 kombinasi perlakuan dari ekstrak bahan nabati (daun nimba, daun cengkeh, kulit jati, kulit pinus, daun ketapang) dan waktu aplikasi (4, 2, dan $4+2$ minggu sebelum tanam). Pengamatan dilakukan terhadap perkembangan patogen, intensitas penyakit, dan pertumbuhan tanaman. Hasil penelitian menunjukkan bahwa seluruh bahan nabati yang digunakan dapat menurunkan populasi patogen tetapi tidak berpengaruh terhadap komponen pertumbuhan tanaman. Ekstrak daun cengkeh yang diberikan pada 4 minggu sebelum tanam merupakan perlakuan terbaik dalam menurunkan populasi patogen (79.22\%).
\end{abstract}

Kata kunci: kesehatan tanah, ekstrak daun cengkeh, tomat, Fusarium oxysporum f.sp. lycopersici 


\section{PENDAHULUAN}

Tomat merupakan jenis sayuran yang banyak digemari orang karena rasanya enak, segar dan sedikit asam serta mengandung banyak vitamin A, C dan sedikit vitamin B (Balai Informasi Pertanian, 1993). Produksi tomat nasional berkisar 3-6 ton ha ${ }^{-1}$, sedangkan produkti-vitas di Pulau Jawa lebih dari 7 ton $\mathrm{ha}^{-1}$ dan masih dapat ditingkatkan dengan penggunaan varietas unggul baru berproduksi tinggi, tahan hama, penyakit, dan cekaman lingkungan, serta teknologi budidaya yang efisien (Baswarsiati et al., 2002).

Tanaman tomat dalam pertumbuhannnya tidak lepas dari serangan OPT, khususnya patogen tanaman yang selalu muncul setiap musim tanam. Hal ini menandakan lahan pertumbuhan tomat tidak sehat dan sudah terkontaminasi patogen, termasuk jamur Fusarium oxysporum Schlecht. f.sp. 1ycopersici (Sacc.) Snyd. et Hans. (Widodo, 2004). Patogen tersebut mampu bertahan dalam tanah dengan jumlah spora mencapai 1000 konidium per gram tanah dan serangannya mulai nampak pada umur 4 minggu setelah tanam dengan intensitas tinggi (Rosmahani et al., 2001).

Berbagai usaha dilakukan petani untuk mengatasi serangan patogen tersebut., Selama ini petani lebih banyak memanfaatkan penggunaan pestisida kimia yang diterapkan di permukaan tanah pada bagian tanam, namun belum mendapatkan hasil memuaskan serta kurang ramah terhadap lingkungan. Penerapan pada tanah akan berdampak pada pencemaran tanah dan matinya organisme sehingga mengganggu keseimbangan ekologi tanah (Agrios, 2005). Penggunaan metode pengendalian tanpa pesti-sida kimia, antara lain dengan pengendalian secara mekanik, memodifikasi lingkungan fisik, penggunaan agensia hayati, serta penggunaan bahan nabati belum banyak dilakukan terhadap tanah untuk mengurangi kontaminan pada tanah pertanaman tomat.

Penelitian ini bertujuan untuk mengidentifikasi jenis bahan nabati (ekstrak daun nimba, daun cengkeh, kulit jati, kulit pinus, dan daun ketapang) dan waktu aplikasi terbaik dalam menekan populasi Fusarium oxysporum f.sp. lycopersici di dalam tanah dan pengaruhnya terhadap komponen pertumbuhan tanaman tomat.

\section{METODE PENELITIAN}

Penelitian ini dilaksanakan di rumah kasa Fakultas Pertanian Universitas Jenderal Soedirman
Purwokerto $(125 \mathrm{~m} \mathrm{dpl})$ selama 6 bulan mulai bulan September 2006 sampai Februari 2007. Sampel tanah yang selalu terkontaminasi patogen F. oxysporum f.sp. lycopersici diambil dari daerah Pratin, Purbalingga (1,000 m dpl.) dan selanjutnya digunakan untuk penyiapan inokulum dan media tanam tomat.

Untuk penyiapan inokulum, sampel tanah diambil $10 \mathrm{~g}$ dan dimasukkan ke dalam Erlenmeyer berisi $90 \mathrm{~mL}$ air steril yang selanjutnya digojok selama 30 menit hingga homogen. Suspensi diambil $1 \mathrm{~mL}$ dan dilakukan seri pengenceran sampai $10^{6}$. Penghitungan konidium jamur dilakukan dengan mengambil suspensi $1 \mathrm{~mL}$, dituang ke medium agar dalam cawan Petri, dan diinkubasi selama tiga hari. Jumlah koloni yang tumbuh diamati dan dihitung.

Ekstrak bahan nabati dibuat dengan metode sebagai berikut. Ekstrak daun nimba dan ekstrak daun ketapang masing-masing dibuat dari $40 \mathrm{~g}$ daun nimba dan daun ketapang yang ditumbuk dan dicampur dalam $1 \mathrm{~L}$ alkohol $2 \%$, serta diendapkan semalam dan disaring (Nursol, 2000). Ekstrak daun cengkeh dibuat dari $40 \mathrm{~g}$ daun cengkeh yang diambil langsung dari pohon dan dikeringkan selama 4 hari yang selanjutnya dicampur $1 \mathrm{~L}$ alkohol $2 \%$ (Dinas Pertanian Jakarta, 2001). Ekstrak kulit kayu jati dan ekstrak kulit kayu pinus masing-masing dibuat dari $50 \mathrm{~g}$ kulit kayu jati dan kulit kayu pinus yang sudah kering dan direndam dalam $400 \mathrm{~mL}$ air steril selama dua minggu, kemudian disaring (Yulia dan Suganda, 1999).

Benih disemai pada bedengan dengan tinggi 10$15 \mathrm{~cm}$. Pada persemaian diberi lindungan berupa kain kasa. Benih disemaikan pada tanah yang telah disterilkan dengan jalan dikukus selama \pm 2 jam dengan jarak antar barisan $5 \mathrm{~cm}$. Persemaian disiram untuk menjaga kelembaban.

Rancangan acak kelompok (RAK) dengan tiga ulangan digunakan untuk mengalokasikan 19 kombinasi perlakuan, yaitu ekstrak daun nimba, ekstrak daun cengkeh, ekstrak kulit jati, ekstrak kulit pinus, ekstrak daun ketapang, dan fungisida sintetis benomil yang masing-masing diaplikasikan pada 4, 2, serta 4 dan 2 minggu sebelum tanam, serta kontrol (tanah terkontaminasi tanpa perlakuan).

Peubah yang diamati adalah kepadatan populasi awal dan akhir $F$. oxysporum f.sp. lycopersici yang diukur dengan satuan unit pembentuk koloni (upk) per gram tanah, masa inkubasi, intensitas penyakit, kandungan senyawa saponin dan tannin (Chairul, 2003), tinggi tanaman, dan jumlah daun pertanaman. Peubah pendukung yang diamati 
adalah $\mathrm{pH}$ tanah dan kandungan nutrisi ( $\mathrm{Ca}$ dan nisbah $\mathrm{C} / \mathrm{N}$ ) dalam tanah, serta suhu udara. Data hasil pengamatan dianalisis dengan analisis varian dengan menggunakan uji $\mathrm{F}(\alpha=5 \%)$ dan DMRT $(\alpha=5 \%)$ dilakukan untuk membandingkan antar rata-rata perlakuan.

\section{HASIL DAN PEMBAHASAN}

\section{Kandungan Senyawa Saponin dan Tannin Pada Bahan Nabati}

Kandungan senyawa saponin ditunjukkan dengan adanya busa atau buih lebih dari $3 \mathrm{~cm}$ dari permukaan larutan setelah 30 menit (Chairul, 2003). Saponin adalah glikosida yang dicirikan kemampuannya menghasilkan busa atau buih bila dikocok dalam air. Hasil pengamatan menunjukkan bahwa ekstrak daun nimba, daun cengkeh, kuli kayu jati, kulit kayu pinus, dan daun ketapang mengandung senyawa saponin. Kandungan senyawa tannin pada bahan nabati yang digunakan dalam perlakuan ditunjukkan dengan adanya warna biru atau biruhitam, sedangkan pengembunan tannin memberikan warna biru-hijau (Chairul, 2003). Kandungan senyawa tannin paling tinggi terdapat pada ekstrak daun ketapang, sedangkan paling rendah pada ekstrak daun nimba (Tabel 1).

\section{Masa Inkubasi penyakit}

Pengamatan terhadap masa inkubasi didasar-kan pada saat pertama kali muncul gejala. Gejala yang muncul pada penelitian ini adalah mengu-ningnya daun bagian bawah, memucatnya tulang daun, dan merunduknya tungkai, sebagai-mana dikemukakan oleh Semangun (1994). Gejala layu fusarium mulai muncul pada 27 hari setelah tanam (hst) pada perlakuan $\mathrm{N}_{2}, \mathrm{~N}_{3}, \mathrm{C}_{1}, \mathrm{C}_{2}, \mathrm{C}_{3}, \mathrm{P}_{1}, \mathrm{~F}_{2}, \mathrm{~F}_{3}$, dan $\mathrm{K}$ (Tabel 2). Gejala yang muncul pada penelitian ini sejalan dengan yang diungkapkan Rosmahani et al. (2001), bahwa serangan $F$. oxysporum f.sp. lycopersici pada umumnya mulai tampak pada umur 4 minggu setelah tanam. Selain itu, serangan $F$. oxysporum f.sp. lycopersici cukup merata dengan intensitas serangan yang cukup tinggi.

Pada perlakuan daun nimba dan cengkeh dengan berbagai waktu aplikasi serta perlakuan $\mathrm{P}_{1}$ (ekstrak pinus 4 minggu sebelum tanam), masih muncul gejala pada 27 hst. Hal ini diduga karena kandungan bahan aktifnya mudah tercuci akibat curah hujan cukup tinggi pada saat penelitian. Hal ini didukung oleh pernyataan Kardinan (2000) bahwa salah satu sifat pestisi-da nabati adalah mudah tercuci dan terurai di alam.Pada perlakuan fungisida sintetis benomil $\left(\mathrm{F}_{2}, \mathrm{~F}_{3}\right)$ gejala masih muncul pada $27 \mathrm{hst}$. Hal ini diduga karena terjadi ketahanan $F$. oxysporum f.sp. lycopersici terhadap fungisida tersebut akibat penggunaan yang benomil secara terus-menerus oleh petani tomat di daerah tempat tanah didapatkan.

Suhu udara juga dapat berpengaruh terhadap pertumbuhan dan perkembangan $F$. oxysporum f.sp. lycopersici. Suhu udara pada saat penelitian berkisar $26-32,5{ }^{\circ} \mathrm{C}$. Menurut Sastrahidayat (1986) bahwa $F$. oxysporum f.sp. lycopersici tidak dapat menginfeksi tanaman pada suhu yang tidak sesuai walaupun faktor lingkungan yang lain sesuai dengan perkembangan patogen; pada suhu antara $25-28{ }^{\circ} \mathrm{C}$, patogen lebih virulen, sedangkan pada suhu 25-30 ${ }^{\circ} \mathrm{C}$ konidium akan berkecambah.

Masa inkubasi yang terlihat lebih lama pada perlakuan $\mathrm{Kt}_{1}$ dan $\mathrm{Kt}_{3}$, yakni gejala terjadi pada 33 hst. Hal ini disebabkan oleh kandungan bahan aktif pada daun ketapang, di antaranya senyawa tannin, seperti punicalin, punicalagin, dan tercatein (Tropical-Aqua World, 2006). Hasil uji tannin dan saponin menunjukkan bahwa kandungan senyawa tannin tertinggi terdapat pada daun ketapang (Tabel 1).

Perlakuan ekstrak kulit jati saat 4 minggu sebelum tanam $\left(\mathrm{J}_{1}\right)$ juga menunjukkan gejala pada $33 \mathrm{hst}$.

Tabel 1. Uji tannin dan saponin pada bahan nabati

\begin{tabular}{lccc}
\hline \multicolumn{1}{c}{ Bahan nabati } & $\begin{array}{c}\text { Tinggi busa dari } \\
\text { permukaan larutan } \\
(\mathrm{cm})\end{array}$ & Warna kontrol & $\begin{array}{c}\text { Warna setelah } \\
\text { ditambah } \mathrm{FeCl}_{3}\end{array}$ \\
\hline Ekstrak daun nimba & 4.7 & Hijau & Biru-agak hitam \\
Ekstrak daun cengkeh & 4.3 & Kuning agak coklat & Biru-hitam \\
Ekstrak kulit kayu jati & 4.7 & Agak kuning & Coklat \\
Ekstrak kulit kayu pinus & 4.3 & Tanwarna & Coklat \\
Ekstrak daun ketapang & 4.6 & Coklat & Hitam pekat \\
\hline
\end{tabular}


Hal ini disebabkan oleh kandungan senyawa saponin pada kulit kayu jati. Selain itu, kulit kayu jati memacu munculnya mikroba antagonis. Hal ini karena kulit kayu memberi pengaruh baik dalam menghambat penyakit tanaman (Hoitink, 1980 dan Hoitink et al., 1996 dalam Yulia dan Suganda, 1999).

\section{Intensitas Penyakit}

Hasil analisis data intensitas penyakit menunjukkan berbeda tidak nyata (Tabel 2). Hal ini berarti berbagai perlakuan bahan nabati belum mampu memengaruhi intensitas penyakit secara nyata. Meskipun demikian dapat diamati bahwa pada pengamatan terakhir (51 hst), intensitas penya- kit layu fusarium terbesar terjadi pada perlakuan dengan fungisida sintetis benomil saat 2 minggu sebelum tanam $\left(\mathrm{F}_{2}\right)$, yaitu sebesar $97.78 \%$, yang hampir sama dengan kontrol $(\mathrm{K})$, yaitu sebesar $97.14 \%$. Perlakuan dengan ekstrak daun ketapang, daun cengkeh, dan daun nimba pada penelitian ini belum mampu menurunkan intensitas penyakit layu fusarium, walaupun semua bahan nabati yang digunakan mengandung positif senyawa tannin dan saponin. Akan tetapi perbedaan intensitas penyakit pada perlakuan bahan nabati juga sejalan dengan tingkat kandungan senyawa saponin dan tannin, yang terlihat dari reaksi positif dari uji tannin dan saponin (Tabel 1).

Tabel 2. Rata-rata masa inkubasi, intensitas penyakit layu Fusarium pada tanaman tomat yang diberi perlakuan

\begin{tabular}{cccccc}
\hline Perlakuan & $\begin{array}{c}\text { Masa } \\
\text { Inkubasi (hst) }\end{array}$ & $\begin{array}{c}\text { Intensitas Penyakit } \dagger \\
51 \mathrm{hst}(\%)\end{array}$ & \multicolumn{3}{c}{ Populasi $\left(\mathrm{x} 10^{6}\right) \mathrm{upk} / \mathrm{g}$ tanah } \\
\cline { 4 - 5 } $\mathrm{N}_{1}$ & 28 & $93.99 \mathrm{a}$ & 23.73 & 20.36 & $3.37 \mathrm{a}$ \\
$\mathrm{N}_{2}$ & 27 & $77.82 \mathrm{a}$ & 23.73 & 19.34 & $4.39 \mathrm{~b}$ \\
$\mathrm{~N}_{3}$ & 27 & $88.89 \mathrm{a}$ & 23.27 & 13.73 & $9.54 \mathrm{~g}$ \\
$\mathrm{C}_{1}$ & 27 & $78.55 \mathrm{a}$ & 23.27 & 4.93 & $18.34 \mathrm{~s}$ \\
$\mathrm{C}_{2}$ & 27 & $86.68 \mathrm{a}$ & 23.27 & 6.73 & $16.54 \mathrm{n}$ \\
$\mathrm{C}_{3}$ & 27 & $79.05 \mathrm{a}$ & 23.27 & 5.67 & $17.60 \mathrm{r}$ \\
$\mathrm{J}_{1}$ & 33 & $84.21 \mathrm{a}$ & 23.27 & 8.97 & $14.30 \mathrm{k}$ \\
$\mathrm{J}_{2}$ & 31 & $68.55 \mathrm{a}$ & 23.27 & 7.96 & 15.311 \\
$\mathrm{~J}_{3}$ & 30 & $86.12 \mathrm{a}$ & 23.27 & 5.98 & $17.29 \mathrm{o}$ \\
$\mathrm{P}_{1}$ & 27 & $91.89 \mathrm{a}$ & 23.27 & 12.47 & $10.80 \mathrm{~h}$ \\
$\mathrm{P}_{2}$ & 28 & $92.81 \mathrm{a}$ & 23.27 & 11.86 & $11.41 \mathrm{i}$ \\
$\mathrm{P}_{3}$ & 32 & $87.50 \mathrm{a}$ & 23.27 & 10.96 & $12.31 \mathrm{j}$ \\
$\mathrm{Kt}_{1}$ & 33 & $75.55 \mathrm{a}$ & 23.27 & 7.76 & $15.51 \mathrm{~m}$ \\
$\mathrm{Kt}_{2}$ & 31 & $88.05 \mathrm{a}$ & 23.27 & 5.73 & $17.57 \mathrm{q}$ \\
$\mathrm{Kt}_{3}$ & 33 & $84.13 \mathrm{a}$ & 23.27 & 5.96 & $17.31 \mathrm{p}$ \\
$\mathrm{F}_{1}$ & 31 & $92.06 \mathrm{a}$ & 23.27 & 15.16 & $8.11 \mathrm{f}$ \\
$\mathrm{F}_{2}$ & 27 & $97.78 \mathrm{a}$ & 23.27 & 17.67 & $5.60 \mathrm{e}$ \\
$\mathrm{F}_{3}$ & 27 & $95.28 \mathrm{a}$ & 23.27 & 18.18 & $5.09 \mathrm{~d}$ \\
$\mathrm{~K}$ & 27 & $97.14 \mathrm{a}$ & 23.27 & 18.77 & $4.50 \mathrm{c}$ \\
\hline
\end{tabular}

$\dagger$ Rata-rata sekolom yang diikuti huruf sama berarti beda tidak nyata pada DMRT $(\alpha=5 \%)$. Data intensitas penyakit yang dianalisis ditransformasi dalam Arc. $\sin \sqrt{x}_{\mathrm{x}} . \mathrm{N}_{1}=$ Ekstrak daun nimba 4 minggu sebelum tanam; $\mathrm{N}_{2}=$ Ekstrak daun nimba 2 minggu sebelum tanam; $\mathrm{N}_{3}=$ Ekstrak daun nimba 4 dan 2 minggu sebelum tanam; $\mathrm{C}_{1}=$ Ekstrak daun cengkeh 4 minggu sebelum tanam; $\mathrm{C}_{2}=$ Aplikasi ekstrak daun cengkeh 2 minggu sebelum tanam; $\mathrm{C}_{3}=$ Ekstrak daun cengkeh 4 dan 2 minggu sebelum tanam; $\mathrm{J}_{1}=$ Ekstrak kulit jati 4 minggu sebelum tanam; $\mathrm{J}_{2}=$ Ekstrak kulit jati 2 minggu sebelum tanam; $\mathrm{J}_{3}=$ Ekstrak kulit jati 4 dan 2 minggu sebelum tanam; $\mathrm{P}_{1}=$ Ekstrak kulit pinus 4 minggu sebelum tanam; $\mathrm{P}_{2}=$ Ekstrak kulit pinus 2 minggu sebelum tanam; $\mathrm{P}_{3}=$ Ekstrak kulit pinus 4 dan 2 minggu sebelum tanam; $\mathrm{Kt}_{1}=$ Ekstrak daun ketapang 4 minggu sebelum tanam; $\mathrm{Kt}_{2}=$ Ekstrak daun ketapang 2 minggu sebelum tanam; $\mathrm{Kt}_{3}=$ Ekstrak daun ketapang 4 dan 2 minggu sebelum tanam; $F_{1}=$ Fungisida sintetis benomil 4 minggu sebelum tanam; $F_{2}=$ Fungisida sintetis benomil 2 minggu sebelum tanam; $F_{3}=$ Fungisida sintetis benomil 4 dan 2 minggu sebelum tanam; $\mathrm{K}=\mathrm{Kontrol}$ (tanah terkontaminan tanpa perlakuan). 
Pada penelitian ini, intensitas penyakit layu fusarium termasuk tinggi dan dapat menyebabkan kerugian besar pada tanaman cabai dan tomat. Tingginya intensitas penyakit dapat terjadi karena pengaruh faktor lingkungan, seperti kelembaban tanah yang tinggi (Sastrahidayat, 1986). Kelembaban tanah pada penelitian berkisar 80-100\% dan kelembaban yang tinggi juga didukung dengan adanya musim penghujan saat tanam, sekalipun. Menurut informasi petani setempat bahwa penyakit layu fusarium juga terjadi setiap musim tanam.

\section{Kepadatan Populasi F. oxysporum f.sp. lycopersici}

Berdasarkan penghitungan populasi $F$. oxysporum f.sp. lycopersici pada tanah awal penelitian ditemukan bahwa tiap gram tanah memiliki kepadatan sebesar $23.73 \times 10^{6}$ upk. Setelah tanaman tomat mulai berbunga terdapat perubahan jumlah kepadatan koloni yang menunjukkan bahwa secara umum, populasi akhir $F$. oxysporum f.sp. lycopersici mengalami penurunan setelah perlakuan (Tabel 2). Penurunan populasi patogen $F$. oxysporum f.sp. lycopersici terbesar terdapat pada perlakuan ekstrak daun cengkeh 4 minggu sebelum tanam $\left(\mathrm{C}_{1}\right)$ dari $23.72 \times 10^{6}$ upk per g tanah menjadi $4.93 \times 10^{6}$ upk per $\mathrm{g}$ tanah, atau terjadi penurunan sebesar $79.22 \%$. Hal ini terjadi karena pada daun cengkeh mengandung positif senyawa tannin dan saponin. Selain itu, pada ekstrak daun cengkeh mengandung senyawa eugenol yang dapat menghambat pertumbuhan dan perkembangan jamur penyebab penyakit, hama, nematoda, dan bakteri (Tombe et al., 1993; Balai Pengkajian Teknologi Pertanian, 2000).

Penurunan populasi $F$. oxysporum f.sp. lycopersici pada kontrol (K) sebesar $33.52 \%$. Penurunan populasi yang lebih rendah dari kontrol juga terjadi pada berbagai perlakuan, yaitu pada perlakuan ekstrak daun nimba 4 dan 2 minggu sebelum tanam $\left(\mathrm{N}_{2}\right)$. Hal ini karena pengaruh waktu perlakuan pada 4 minggu sebelum tanam lebih lama pengaplikasiannya, sehingga bahan aktif pada daun nimba yang diberikan ke tanah sudah terurai dan tercuci. Perlakuan ekstrak daun nimba 4 dan 2 minggu sebelum tanam $\left(\mathrm{N}_{3}\right)$ lebih besar terjadi penurunan populasi patogen $F$. oxysporum f.sp. lycopersici daripada perlakuan ekstrak nimba lain. Ekstrak daun nimba diduga mengandung zat azadiraktin yang dapat menghambat perkecambahan spora dan konidium jamur (Musa, 2006).

Pada perlakuan ekstrak daun ketapang terjadi penurunan populasi lebih besar dibandingkan dengan perlakuan ekstrak kulit kayu jati, kulit kayu pinus, serta benomil. Hal ini karena pada ekstrak daun ketapang mengandung senyawa tannin dan saponin, sedangkan pada kulit kayu jati dan pinus hanya mengandung senyawa saponin (Tabel 1). Penurunan populasi patogen $F$. oxysporum f.sp. lycopersici selain karena pengaruh perlakuan juga karena faktor lingkungan. Sastrahidayat (1986) menyatakan bahwa kondisi lingkungan sangat menentukan perkembangan patogen. Penurunan populasi patogen dalam tanah akan mengakibatkan kondisi tanah yang semakin sehat, tanah mengandung sedikit patogen, dan intensitas penyakitnya lebih rendah (Pangkhurst, 1997).

\section{Komponen Pertumbuhan tomat}

Semua perlakuan yang diberikan tidak mempegaruhi tinggi tanaman secara nyata (Tabel 3) karena penyakit menyerang hampir pada seluruh tanaman yang menyebabkan kelayuan dan terhambatnya pertumbuhan. Meskipun demikian, dapat dilihat bahwa selisih tinggi tanaman tertinggi terdapat pada perlakuan $\mathrm{P}_{3}$ (ekstrak kulit kayu pinus 4 dan 2 minggu sebelum tanam), yaitu sebesar $45.67 \mathrm{~cm}$, sedangkan pada $\mathrm{K}$ (kontrol) sebesar $35.28 \mathrm{~cm}$. Selisih tinggi tanaman terendah pada perlakuan $\mathrm{F}_{2}$ (fungisida sintetis benomil 2 minggu sebelum tanam), yaitu $22.34 \mathrm{~cm}$.

Rata-rata jumlah daun terbanyak terdapat pada perlakuan $\mathrm{Kt}_{3}$ (ekstrak daun ketapang pada 4 minggu dan 2 minggu sebelum tanam), yaitu 8.2 helai, dan untuk jumlah paling sedikit pada perlakuan $\mathrm{Kt}_{2}$ (ektrak daun ketapang 2 minggu sebelum tanam), yaitu 6.93 helai. Jumlah daun yang ada juga berkaitan dengan intensitas penyakit dari masing-masing perlakuan. Perlakuan Kt3 menyebabkan intensitas penyakit relatif lebih rendah dibanding Kt2 (Tabel 3).

\section{KESIMPULAN}

Penggunaan bahan nabati (ekstrak daun nimba, daun cengkeh, kulit jati, kulit pinus, dan daun ketapang) belum mampu menekan intensitas penyakit layu fusarium pada tanaman tomat dan tidak berpengaruh terhadap komponen pertumbuhan tanaman tomat. Populasi Fusarium oxysporum f.sp. lycopersici di dalam tanah mengalami penurunan akibat penggunaan bahan nabati tersebut. Penurunan populasi tertinggi terdapat pada perlakuan ekstrak daun cengkeh yang diterapkan pada 4 minggu sebelum tanam, yaitu sebesar $79.22 \%$. 
Tabel 3. Rata-rata jumlah daun dan tinggi tanaman

\begin{tabular}{ccc}
\hline Perlakuan & $\begin{array}{c}\text { Jumlah Daun } \dagger \\
\text { Terakhir }\end{array}$ & $\begin{array}{c}\text { Selisih Tinggi† } \\
\text { Tanaman }(\mathrm{cm})\end{array}$ \\
\hline $\mathrm{N}_{1}$ & $7.73 \mathrm{a}$ & $34.28 \mathrm{a}$ \\
$\mathrm{N}_{2}$ & $7.38 \mathrm{a}$ & $40.78 \mathrm{a}$ \\
$\mathrm{N}_{3}$ & $7.03 \mathrm{a}$ & $40.71 \mathrm{a}$ \\
$\mathrm{C}_{1}$ & $7.70 \mathrm{a}$ & $41.59 \mathrm{a}$ \\
$\mathrm{C}_{2}$ & $7.87 \mathrm{a}$ & $33.89 \mathrm{a}$ \\
$\mathrm{C}_{3}$ & $7.93 \mathrm{a}$ & $38.23 \mathrm{a}$ \\
$\mathrm{J}_{1}$ & $7.20 \mathrm{a}$ & $37.50 \mathrm{a}$ \\
$\mathrm{J}_{2}$ & $8.03 \mathrm{a}$ & $31.23 \mathrm{a}$ \\
$\mathrm{J}_{3}$ & $7.43 \mathrm{a}$ & $34.73 \mathrm{a}$ \\
$\mathrm{P}_{1}$ & $8.03 \mathrm{a}$ & $38.45 \mathrm{a}$ \\
$\mathrm{P}_{2}$ & $7.60 \mathrm{a}$ & $38.56 \mathrm{a}$ \\
$\mathrm{P}_{3}$ & $6.97 \mathrm{a}$ & $45.67 \mathrm{a}$ \\
$\mathrm{Kt}_{1}$ & $7.63 \mathrm{a}$ & $37.64 \mathrm{a}$ \\
$\mathrm{Kt}_{2}$ & $6.93 \mathrm{a}$ & $36.73 \mathrm{a}$ \\
$\mathrm{Kt}_{3}$ & $8.20 \mathrm{a}$ & $36.84 \mathrm{a}$ \\
$\mathrm{F}_{1}$ & $7.17 \mathrm{a}$ & $24.34 \mathrm{a}$ \\
$\mathrm{F}_{2}$ & $7.03 \mathrm{a}$ & $22.34 \mathrm{a}$ \\
$\mathrm{F}_{3}$ & $7.30 \mathrm{a}$ & $35.84 \mathrm{a}$ \\
$\mathrm{K}$ & $7.10 \mathrm{a}$ & $35.28 \mathrm{a}$ \\
\hline
\end{tabular}

$\dagger$ Rata-rata sekolom yang diikuti huruf sama berarti beda tidak nyata padaDMRT $(\alpha=5 \%)$. Data dianalisis dan ditransformasi dalam $\sqrt{ } \mathrm{x}$.

\section{DAFTAR PUSTAKA}

Agrios, G.N. 2005. Plant Pathology. $5^{\text {th }}$ ed. Elsevier Academic Press, Burlinton.

Balai Informasi Pertanian. 1993. Bercocok tanam tomat (Lycopersicum esculentum Mill.). Lembar Informasi Pertanian Agdex 266/20 Nopember 1993. (On-line). http://www.pustaka.deptan.go.id/ agritech/ppua0145. pdf [16 Agustus 2006].

Balai Pengkajian Teknologi Pertanian. 2000. Piretrum Nimba. Lembar Informasi Pertanian (On-line). http://jabar.litbang.deptan.go.id/pdf/liptan/nabati.pdf [20 Agustus 2006].

Baswarsiti, D. Setyorini, Suhardi, D. Rahmawati, E. Retnaningtyas, dan I.R. Dewi. 2002. Hasil Uji Adaptasi calon varietas Unggul Tomat di Lahan Kering dataran Rendah. Laporan Akhir Penelitian BPTP Karangploso (On-line). http://www.bptp-jatimdeptan.go.id/Templates/Templates/06-Baswarsiat.pdf [16 Agustus 2006].
Chairul. 2003. Pusat Penelitian Biologi LIPI. Identifikasi Secara Cepat Bahan Bioaktif Pada Tumbuhan Di Lapangan. Berita Biologi 6(4): 621-629.

Dinas Pertanian Jakarta. 2001. Pestisida Nabati. (On-line). http://www.jakarta.go.id/distan/BERITA/Pestisida\% 20Nabati.htm. [16 Agustus 2006].

Kardinan, A. 2000. Pestisida Nabati: Ramuan dan Aplikasi. Panebar Swadaya, Jakarta. Phytopathol. 36: 453-483.

Musa, A.S. 2006. Potensi Beberapa Pestisida Nabati Dalam Upaya Penyehatan Tanah Pada Tanaman Padi In Planta. Skripsi. Fakultas Pertanian, Universitas Jenderal Soedirman, Purwokerto.

Nursol. M. 2000. Pembuatan Pestisida Nabati Secara Sederhana \& Aplikasinya di Lapangan. Pelatihan Perbanyakan Agensia Hayati Bagi Petugas Penelitian, BPTP, Medan.

Pankhurst, C.E. 1997. Biodiversity of Soil Organism and Indicator of Soil Health.. In: C.E. Pankhurst, B.M. Double, and V.V.S.R Gupta (Eds.). Biological Indicators of Soil Health. CAB International, New York. pp. 297-324

Rosmahani, L., E. Korlina, M. Soleh, dan D. Setyorini. 2001. Pengkajian Pemanfaatan Biopestisida Dan Pupuk Hayati Mendukung Pengelolaan Tanaman Terpadu Pada Tomat (On-line). http://www.bptpjatim-deptan.go.id/ [16 Agustus 2006].

Sastrahidayat, I.R. 1986. Ilmu Penyakit Tumbuhan. Usaha Nasional, Surabaya.

Semangun, H. 1994. Penyakit-penyakit Tanaman Hortikultura Di Indonesia. Gadjah Mada University Press, Yogyakarta.

Tombe, M., N.Nurawan, dan Sukamto. 1993. Penelitian penggunaan daun cengkeh dalam pengendalian penyakit busuk batang panili. Prosiding Seminar Sehari Penelitian Dalam Rangka Pemanfaatan Pestisida Nabati, Bogor, 1-2 Desember. pp. 28-36.

Tropical-Aqua Word. 2006. Terminalia cattapa L. (Online). http://www.tropical-aquaworld.com/terminaliae. htm. [8 September 2006].

Widodo. 2004. Status Fusarium Sebagai Patogen Tanaman di Indonesia. Dalam: L. Soesanto (Ed.), Prosiding Simposium Nasional I tentang Fusarium. Purwokerto. 26-27 Agustus 2004.

Yulia, E.T. dan Suganda. 1999. Pengendalian Penyakit Layu Bakteri Ralstonia solanacearum Pada Tanaman Tomat Dengan Rendaman Kulit Jati, Mahoni, Pinus dan Suren. Prosiding Kongres Nasional XV \& Seminar Ilmiah PFI, 16-18 September 1999, Purwokerto. pp. 300-305. 